\title{
Direct Induced Effects of Standard and Modified Radiotherapy Protocol on Surface Structure of Hard Dental Tissue
}

\section{Izravno inducirani učinci standardnoga i modificiranog radioterapijskog protokola na površinsku strukturu tvrdih zubnih tkiva}

\author{
${ }^{1}$ Department of Endodontics and Restorative Dental Medicine, School of Dental Medicine Zagreb \\ Zavod za endodonciju i restaurativnu dentalnu medicinu Stomatološkog fakulteta, Zagreb, Hrvatska \\ 2 Health Center Centar, Zagreb \\ Dom zdravlja Centar, Zagreb, Hrvatska \\ ${ }^{3}$ PhD student, School of Dental Medicine, University of Zagreb, Croatia \\ doktorand Stomatološkog fakulteta Sveučilišta u Zagrebu, Hrvatska \\ ${ }^{4}$ Department of Oncology, Radiotherapy Unit, University Hospital Centre Zagreb, Zagreb \\ Odjel za onkologiju - Jedinica za radioterapiju KBC-a Zagreb, Zagreb, Hrvatska
}

\begin{abstract}
Introduction: Radiotherapy is used to treat neo plasmatic lesions and the common side effects of this process are pain, swelling and sensitivity of mucous membranes in domain of radiation, reduced salivation, caries, and periodontal disease and, in total, low life quality. The purpose of this research was to estimate the outcome of direct irradiation on physical and surface characteristics of hard dental tissues. Material and methods: Twenty, caries free third molars were involved in the research. Prior to different submission protocols, tooth halves were randomly assigned to subject and control groups by using a draw method. The first group $(n=20)$ was submitted to conventional irradiation protocol ( 2 Gy for 35 days), second group ( $n=20$ ) was submitted to one powerful, exploratory dose of $70 \mathrm{~Gy}$. Each sample served as its own control. Radiation was performed with a linear accelerator radiotherapy unit. The surface microhardness and roughness were measured at the beginning (initially), and upon completion of irradiation procedure. The average change in microhardness and roughness after different treatments was compared by t-test for independent samples. Normality was tested by the Shapiro-Wilk test. Results: Significant differences were found after the standard radiation protocol and the exploratory dose of $70 \mathrm{~Gy}$, with decreased mean microhardness and increased mean roughness $(p<0.001)$ of both hard dental tissues. Enamel and dentin surface microhardness and roughness did not vary notably with regards to different irradiation protocols. Conclusion: Head and neck conventional irradiation protocol leads to possible breakdown of enamel and dentin with reduced microhardness and increased surface roughness regardless of used irradiation protocol.
\end{abstract}

Received: August 22, 2021

Accepted: October 20, 2021

Address for correspondence Assoc.prof. Eva Klarić Sever University of Zagreb

School of Dental Medicine Department of Endodontics and Restorative Dentistry Gundulićeva 5, 10000 Zagreb, Croatia eklaric@sfzg.hr

MeSH terms: Dentin; Dental Enamel; Surface Properties; Radiotherapy; Long Term Adverse Effects

Author keywords: Conventional Irradiation; Vickers Hardness; Roughness; Hard Dental

\section{Introduction}

Head neoplasms are conditions that involve mucosa and hard structures of that area, including the oral cavity (1). In comparison to different malignant diseases, the prevalence of this carcinoma has been rapidly upgrowing, mostly that of the tongue, salivary glands and hypopharynx region $(2,3)$. Irradiation therapy is used in combination with chemotherapy, with usual outcomes such as pain, swelling and sensitivity of mucous membranes, hyposalivation, which can lead to early cervical tooth decay destruction, periodontal tissue damage, and, in the end, decreased life quality $(4,5)$. Saliva has many preventive goals; hence a possible lack or complete loss of saliva in patient's mouth can lead to increasing development of tooth decay because of increased acidity
Uvod

Novotvorine glave i vrata bolesti su koje zahvaćaju sluznicu i črrsta tkiva u tom području, uključujući i usnu šupljinu (1). U usporedbi s različitim zloćudnim bolestima, prevalencija tih karcinoma ubrzano raste, najviše rak jezika, žlijezda slinovnica i hipofarinksa $(2,3)$. Terapija zračenjem primjenjuje se u kombinaciji s kemoterapijom, a najčešćc nuspojave su bol, oteklina i osjetljivost sluznica te hiposalivacija, što može potaknuti rani razvoj cervikalnog karijesa, oštećenje parodontnog tkiva i na kraju smanjiti kvalitetu života (4, 5). Slina ima mnogobrojne zaštitne učinke, pa njezin mogući nedostatak ili potpuni gubitak u pacijentovim ustima može završiti ubrzanom pojavom karijesa zbog povećane kiselosti i niskoga $\mathrm{pH}$ te manjom mogućnošću osiguranja normalne 
and low $\mathrm{pH}$, and due to reduced likelihood to ensure a normal microflora in human mouth. It has been confirmed that irradiation can result in possible degradation of hard dental tissues, and this is the reason for rapid growth of decay in treated patients (6). A reduced amount of saliva and enlarged plaque generation lead to periodontal diseases, resulting in premature tooth loss; therefore it essential to provide correct tooth brushing techniques $(7,8)$. An ever-increasing number of studies are focused on the effects of irradiation on hard dental tissues, with specific focus on potential changes in microhardness and microstructure of teeth $(9,10)$, but allconquering evaluations of direct irradiation on hard tissues are deficient. Dose amount also plays a significant role. Low tooth breakage appears beneath $30 \mathrm{~Gy}$ irradiation; increasing with doses larger than $60 \mathrm{~Gy}$ which is a consequence of hyposalivation (11). The amounts exceeding 60 Gy resulted in reduced surface hardness, modification in elasticity and increased likelihood of hard tissue breakage $(12,13)$. Finally, head and neck irradiation procedures can lead to potential tooth tissues damage rising with the amount of the entire received irradiation. (11).

Patients suffering from malignant diseases of head and neck need to be warned about potential side effects and need for adequate professional dental procedures. More often dental checkups are advised, with proper oral hygiene in combination with use of topical fluorinated pastes, gels or varnishes. (14-16). Therefore, it is also very important for our patients to examine the effect of irradiation on enamel and dentin and to develop good treatment plans in order to impede potential formations of early cervical caries. Providing better oral health and examining the role of hard tissue damage and formation of radiation caries or enamel and dentin erosion on vestibular and occlusal part as the consequence of irradiation therapy should be one of the main goals.

The objective of the study was to investigate the effects of direct irradiation on surface hardness and roughness of human enamel and dentin. The null hypotheses were: I) there will not be any differences in points of surface hardness and roughness between the teeth without irradiation effects and the teeth subjected to irradiation (II) there will not be any distinctions between various irradiation protocols in point of surface hardness and roughness.

\section{Material and methods}

\section{Specimen preparation}

Twenty fresh, intact third molars were used in this study. Teeth were cleansed and conserved in 1\% chloramine dilution. The application of extracted molars was authorized by the Ethics Committee of the School of Dental Medicine, University of Zagreb and University Hospital Centre Zagreb, Croatia. The roots were removed from the coronal portion with a precise diamond saw (Isomet, Buehler Dusseldorf, Germany) around $2 \mathrm{~mm}$ beneath the enamel-cement connection. Coronal parts were kept in distilled water at $4^{\circ} \mathrm{C}$. After the coronal parts had been cleansed, they were built in transparent acrylate (AcryFix Kit; Struers, Balerrup, Denmark). Prior to slicing of the coronal parts in halves the spec- mikroflore u ljudskim ustima. Potvrđeno je da zračenje može rezultirati degradacijom čvrstih zubnih tkiva, a to je razlog za brzi razvoj karijesa kod liječenih bolesnika (6). Smanjena količina sline i povećano stvaranje plaka potiču nastanak parodontne bolesti, što za posljedicu ima raniji gubitak zuba, pa je prijeko potrebno upotrijebiti ispravnu tehniku četkanja zuba i održavanja oralne higijene $(7,8)$. Sve je više studija usmjereno na učinak zračenja na strukturu tvrdih zubnih tkiva, $s$ posebnim fokusom na potencijalnu promjenu mikrotvrdoće i mikrostrukture zuba $(9,10)$, ali nedostaje sveobuhvatna procjena izravnoga učinka zračenja na tvrda zubna tkiva. Količina doze također je veoma važna. Manja oštećenja nastaju kada je sveukupna doza zračenja manja od 30 greja (Gy), a povećava se s dozama većima od 60 greja, što je posljedica hiposalivacije (11). Količine veće od 60 greja rezultirale su smanjenom površinskom tvrdoćom, promjenom elastičnosti i povećanim mogućnostima puknuća tvrdih zubnih tkiva $(12,13)$. Konačno, postupak zračenja glave i vrata može povećati oštećenja tkiva zuba koja rastu s količinom cjelokupnoga primljenog zračenja (11).

Pacijente koji boluju od malignih bolesti glave i vrata potrebno je upozoriti na moguće kasnije nuspojave i uputiti ih na adekvatne i stručne stomatološke zahvate. Savjetuju se češći stomatološki pregledi, uz pravilnu oralnu higijenu u kombinaciji s primjenom lokalnih fluoridiranih pasta, gelova ili lakova $(14-16)$. Zato je za pacijente također vrlo važno da im se ispita učinak zračenja na caklinu i dentin te dobro planira zaustavljanje potencijalnog nastanka ranoga cervikalnog karijesa. Osiguravanje boljega oralnog zdravlja i ispitivanje učinka oštećenja tvrdoga tkiva i nastanka karijesa zračenjem ili erozije cakline i dentina na vestibularnim ili okluzalnim plohama kao posljedice terapije zračenjem, trebao bi biti jedan od glavnih ciljeva.

Svrha rada bila je ispitati učinak izravnoga zračenja na površinsku tvrdoću i hrapavost ljudske cakline i dentina. Nulte hipoteze bile su: I) nema razlike u površinskoj tvrdoći i hrapavosti između zuba bez učinka zračenja i zuba koji su podvrgnuti postupku izravnoga zračenja, (II) nema razlike u površinskoj tvrdoći i hrapavosti između različitih protokola zračenja.

\section{Materijal i metode}

\section{Priprema uzoraka}

U ovom istraživanju korišteno je dvadeset svježih, netaknutih trećih kutnjaka. Zubi su očišćeni i pohranjeni u 1-postotnoj otopini kloramina. Primjenu ekstrahiranih kutnjaka odobrilo je Etičko povjerenstvo Stomatološkog fakulteta Sveučilišta u Zagrebu i KBC-a Zagreb. Korijeni su odrezani od koronalnoga dijela preciznom dijamantnom pilom (Isomet, Bühler Düsseldorf, Njemačka) oko $2 \mathrm{~mm}$ ispod spoja cakline i cementa. Dijelovi krune čuvani su u destiliranoj vodi na temperaturi od $4{ }^{\circ} \mathrm{C}$. Nakon čišćenja koronalnog dijela uloženi su u prozirni akrilat (AcryFix Kit; Struers, Balerrup, Danska). Prije rezanja koronalnih dijelova na polovine, uzorci su nasumično razvrstani prema postupku zračenja i kontrolnim 
imens were randomly sorted out to irradiation procedure and control groups by applying a lottery model. Each crown half $(n=40)$, served for concurrent enamel and dentin surface hardness and roughness measurements as the surface was flat, and both hard tissues were free of acrylic resin. Group one (1) $(\mathrm{n}=20)$ was subjected to usual irradiation procedure $(2 \mathrm{~Gy}$ for 35 days), group two (2) ( $\mathrm{n}=20)$ was subjected to single probationary exposition of $70 \mathrm{~Gy}$. Each specimen served as its own control. (Figure 1). Specimens were kept in distilled water at $37{ }^{\circ} \mathrm{C}$ (Domel Incubator, Domel d.o.o, Zelezniki, Slovenia) amongst two metering.

To measure both enamel and dentin surface hardness and roughness, coronal parts were built in transparent acrylate with the buccal or palatal surfaces oriented upwards, collateral with stand and without any resin on top. Specimens of the buccal or palatal surfaces were finely furbished with discs (Water Proof Silicon Carbide Paper, 4000 grits; Buehler, Dusseldorf, Germany) and $1.0 \mu \mathrm{m}, 0.3$ and 0.05 $\mu \mathrm{m}$ professional polishing silicon granules (Buehler, Dusseldorf, Germany). The polishing procedure was carried out using polishing appliance (Minitech 250, Presi, France). After that, samples were washed in distilled water.

\section{Irradiation protocol}

After initial microhardness and surface roughness testing, the samples were positioned on a little vitreous pad (Thermo Scientific, Portsmouth, NH, USA) with adhesive wax (Kefo, skupinama primjenom modela lutrije. Svaka polovina krunice $(n=40)$ služila je za istodobna mjerenja tvrdoće i hrapavosti površine cakline i dentina jer je površina bila ravna, a oba tvrda tkiva nisu na sebi imala akrilatnu smolu. Prva skupina (1) $(\mathrm{n}=20)$ bila je podvrgnuta uobičajenom postupku zračenja (2 Gy tijekom 35 dana), a druga (2) je bila $(\mathrm{n}=20)$ podvrgnuta jednom pokusnom, eksperimentalnom zračenju od 70 greja. Svaki je uzorak služio kao vlastita kontrola (slika 1.). Uzorci su između dvaju mjerenja bili pohranjeni u destiliranoj vodi na temperaturi od $37^{\circ} \mathrm{C}$ (Domel inkubator, Domel d.o.o., Železniki, Slovenija).

Za mjerenje tvrdoće i hrapavosti površine cakline i dentina, koronarni dijelovi zuba uloženi su u prozirni akrilat s bukalnim ili palatinalnim površinama okrenutima prema gore, paralelnima s postoljem i bez akrilata na površini. Uzorci bukalne ili palatinalne površine bili su polirani finim diskovima (vodootporni papir od silicijeva karbida, 4000 granulacija; Bühler, Düsseldorf, Njemačka) i 1,0 $\mu \mathrm{m}, 0,3$ i $0,05 \mu \mathrm{m}$ profesionalnim silikonskim granulama za poliranje (Bühler, Düsseldorf). Postupak poliranja obavljen je uređajem za poliranje (Minitech 250, Presi, Francuska). Nakon toga uzorci su isprani u destiliranoj vodi.

\section{Postupak zračenja}

Nakon početnoga ispitivanja mikrotvrdoće i hrapavosti površine, uzorci su postavljeni na malo stakleno postolje (Thermo Scientific, Portsmouth, NH, SAD) s ljepljivim

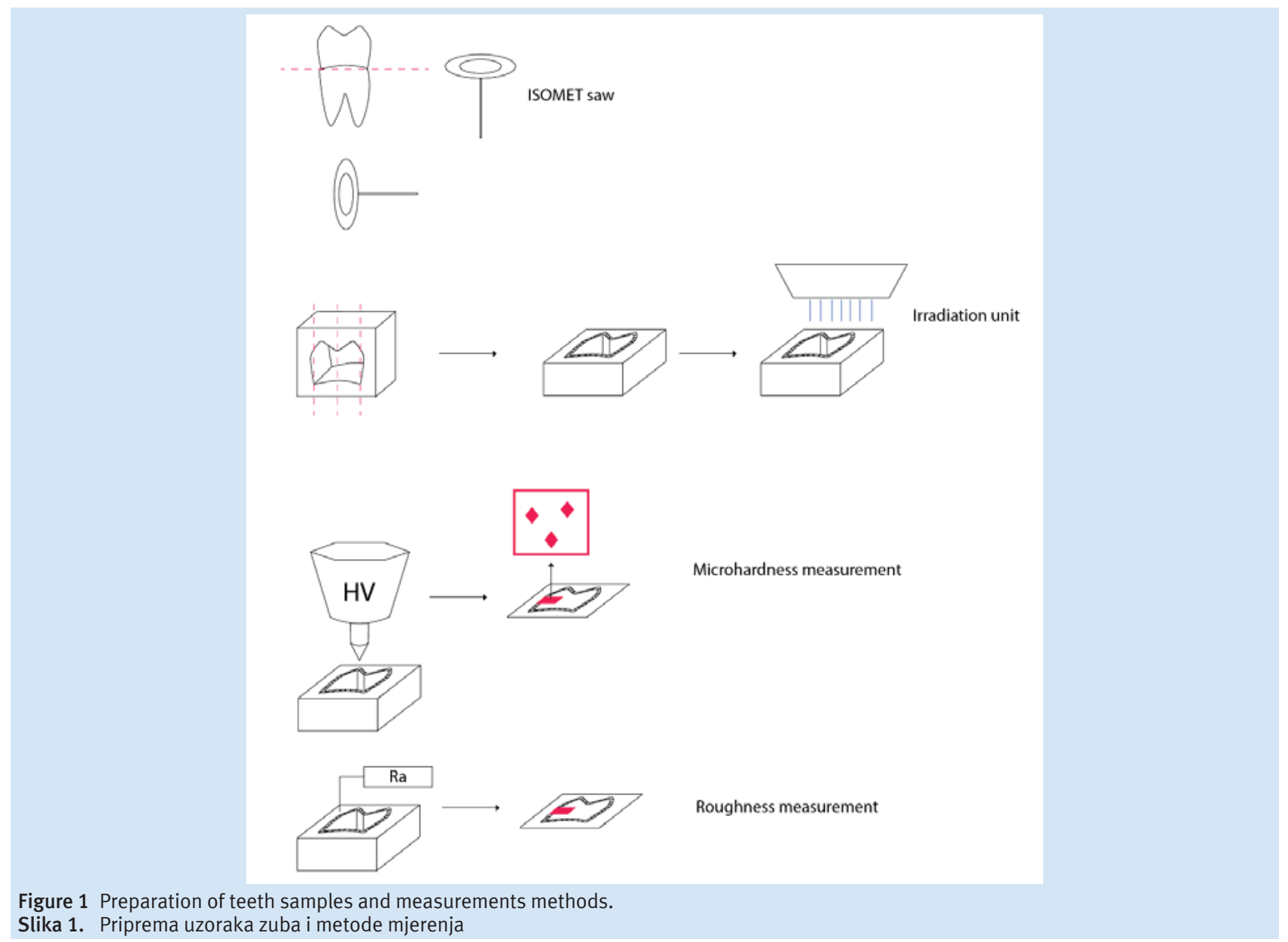


Sisak, Croatia) and located with the buccal surface upward. For conversion of head and neck irradiation protocol, samples in group 1 were irradiated with 2 Gy doses, per 5 days during one week. This procedure was repeated for 7 weeks in total to accumulate $70 \mathrm{~Gy}$ (frequent oral cancer dosage). Throughout the weekend time specimens were not exposed to irradiation (17). Prepared specimens in group 2 were subject to single probationary exposition of $70 \mathrm{~Gy}$. Irradiation procedure was done at Department of Oncology, University Hospital Centre Zagreb with a linear accelerator Siemens Primus (Siemens Healtheneers AG, Erlangen, Germany. 6 MV irradiation ray was applied with SSD (source to surface distance) of $100 \mathrm{~cm}$. Two $\mathrm{cm}$ of construction material was put over and beneath specimens to provide satisfying beam dissipation. The control specimens were stored in distilled water with no irradiation. After different irradiation exposition protocols had been used, coronal samples were washed with distilled water.

\section{Surface hardness measurements}

The microhardness of hard tissues in groups 1 and 2 was evaluated at the beginning (initial), and upon completion of the irradiation procedure. Measuring was provided by Vickers microhardness testing machine (ESI Prüftechnik GmbH, Wendlingen, Germany). A pyramidal shaped diamond peak was applied on specimen surface using pressure of $100 \mathrm{~g}$ during $10 \mathrm{~s}$. Vickers measurements (VHN) were performed at three various parts on both hard tissues: superficial part, middle, and inner part (with $50 \mu \mathrm{m}$ interspace) and mean Vickers hardness values were calculated. Microhardness test was done prior to and upon irradiation so that every specimen served as its own control.

\section{Surface roughness measurements}

Surface roughness $(\mu \mathrm{m})$ of hard tissues in groups 1 and 2 were evaluated at the beginning (initial), and completion of irradiation procedure using transferable superficial roughness testing machine (Mitutoyo Surftest SJ-210 Series 178, Houston, USA) set at a $0.25 \mathrm{~mm}$ cut-off, and $0.2 \mathrm{~mm} / \mathrm{s}$ speed. Evaluations were done at three different parts and average roughness worth was calculated. Roughness test was done prior to evaluation and beyond irradiation so that every specimen subserved as its own control.

\section{Statistical analysis}

The average changes in surface hardness and roughness after different treatments were compared by t-test for independent samples. In all experimental groups, the data met the assumption of normality. Normality was tested by the Shapiro-Wilk test and by review of asymmetry and roundness indicators. In case of inhomogeneity of variance between experimental groups, the Cochran test was used instead of the standard $\mathrm{t}$-test. The average change in microhardness or roughness after irradiation compared to the initial measurement was compared by t-test for dependent samples. If the values divergent significant from the standard division, the Wilcoxon Signed Rank test was used instead of the t-test. Data were evaluated at a significate degree of 0.05. Evaluation was made using SAS System program (SAS Institute Inc., North Carolina, USA). voskom (Kefo, Sisak, Hrvatska) i usmjereni bukalnom površinom prema gore. Za provedbu protokola zračenja glave i vrata, uzorci u skupini 1 izloženi su 5 dana tijekom jednog tjedna dozi od 2 greja. Taj se postupak ponavljao ukupno 7 tjedana kako bi se akumuliralo 70 greja (standardni postupak zračenja kod karcinoma glave i vrata). Tijekom vikenda uzorci nisu bili zračeni. Pripremljeni uzorci u skupini 2 podvrgnuti su jednoj eksperimentalnoj dozi zračenja od 70 greja. Postupak je proveden na Odjelu za onkologiju KBCa Zagreb linearnim akceleratorom Siemens Primus (Siemens Healtheneers AG, Erlangen, Njemačka). Zraka zračenja od 6 MV primijenjena je SSD-om (od izvora do površine) od 100 $\mathrm{cm}$. Dva centimetra konstrukcijskoga materijala postavljeno je iznad uzoraka i ispod njih da bi se osigurala zadovoljavajuća disipacija snopa zračenja. Kontrolni uzorci pohranjeni su u destiliranoj vodi bez zračenja. Nakon izlaganja različitim protokolima zračenja, uzorci su isprani destiliranom vodom.

\section{Mjerenja površinske tvrdoće}

Mikrotvrdoća tvrdih tkiva u skupinama 1 i 2 mjerena je na početku (početna) i završetku postupka zračenja. Mjerenje je obavljeno uređajem za ispitivanje mikrotvrdoće Vickers (ESI Prüftechnik GmbH, Wendlingen, Njemačka). Dijamantni vrh piramidalnog oblika utisnuo se u površinu uzorka pritiskom od 100 grama tijekom 10 sekunda. Vrijednosti Vickersove mikrotvrdoće (VHN) mjerene su na trima različitim dijelovima na oba tvrda tkiva: površinskom, srednjem i unutarnjem dijelu (s međuprostorom od $50 \mu \mathrm{m}$ ) i izračunate su srednje vrijednosti Vickersove tvrdoće. Mikrotvrdoća je ispitivana prije zračenja i poslije toga postupka tako da je svaki uzorak služio kao vlastita kontrola.

\section{Mjerenja površinske hrapavosti}

Površinska hrapavost $(\mu \mathrm{m})$ tvrdih tkiva u skupinama $1 \mathrm{i}$ 2 procijenjena je na početku (početno) i poslije završetka postupka zračenja prijenosnim strojem za ispitivanje površinske hrapavosti (Mitutoyo Surftest SJ-210 Series 178, Houston, SAD) koji je postavljen na vrijednosti od $0,25 \mathrm{~mm}$ cut-off, i brzinu od $0,2 \mathrm{~mm} / \mathrm{s}$. Mjerenja su obavljena na trima različitim dijelovima i izračunata je prosječna vrijednost hrapavosti. Hrapavost je ispitivana prije zračenja i poslije toga postupka tako da je svaki uzorak služio kao vlastita kontrola.

\section{Statistička analiza}

Prosječne promjene površinske tvrdoće i hrapavosti nakon različitih tretmana uspoređene su t-testom za nezavisne uzorke. $U$ svim eksperimentalnim skupinama ispunjena je pretpostavka o približno normalnoj raspodjeli podataka. Normalnost je testirana Shapiro-Wilkovim testom. U slučaju nehomogenosti varijance između eksperimentalnih skupina, umjesto standardnoga t-testa korišten je Cochranov test. Prosječna promjena mikrotvrdoće ili hrapavosti nakon zračenja, $\mathrm{u}$ usporedbi s početnim mjerenjem, uspoređena je t-testom za zavisne uzorke. Ako su se vrijednosti značajno razlikovale od standardne podjele, umjesto t-testa korišten je Wilcoxonov Signed Rank test. Podatci su procijenjeni signifikantnim stupnjem od 0,05. Procjena je obavljena u programu SAS System (SAS Institute Inc., Sjeverna Karolina, SAD). 


\section{Results}

After both, the usual irradiation procedure (2 Gy for 35 days), or one single probationary exposition of $70 \mathrm{~Gy}$, there was a statistically significant decrease in the mean surface hardness of both hard dental tissues $(<0.001)$ (Table 1$)$. The alteration in surface hardness of enamel after radiation exposition did not vary significantly in terms of irradiation type and dosage $(p=0.867)$. The change in dentin surface hardness after irradiation did not vary statistically significantly in terms to irradiation type and dosage $(\mathrm{p}=0.461)$. The change in surface hardness after usual irradiation procedure did not differ significantly between enamel and dentin $(\mathrm{p}=0.491)$. The alteration in surface hardness after single probationary exposition of $70 \mathrm{~Gy}$ did not differ significantly between the enamel and dentin ( $\mathrm{p}=0.798)$ (Figure 2-5).

After both, the usual irradiation procedure (2 Gy for 35 days), and/or one single probationary exposition of $70 \mathrm{~Gy}$, there was a statistically significant increase in the mean surface roughness of both hard dental tissues $(<0.001)$ (Table 2). The alteration in enamel roughness after radiation exposition did not vary significantly in terms of irradiation type and dosage $(p=0.282)$. The change in dentin roughness did not differ significantly with respect to irradiation type $(\mathrm{p}=0.462)$. The change in roughness after usual irradiation procedure did not differ significantly between the enamel and dentin $(p=0.485)$. The change in roughness after one single probationary exposition of $70 \mathrm{~Gy}$ did not differ significantly between the enamel and dentin $(\mathrm{p}=0.081)$ (Figure 6-9).

\section{Rezultati}

Nakon oba uobičajena postupka ozračivanja (2 Gy tijekom 35 dana), ili jedne eksperimentalne ekspozicije od 70 greja, statistički je značajnije smanjena srednja površinska tvrdoća obaju tvrdih zubnih tkiva $(<0,001)$ (tablica 1.). Promjena površinske tvrdoće cakline nakon izlaganja zračenju nije značajno varirala kad je riječ o vrsti zračenja i dozi ( $p=$ $0,867)$. Promjena tvrdoće površine dentina nakon ozračivanja nije se statistički značajno razlikovala s obzirom na vrstu zračenja i dozu $(\mathrm{p}=0,461)$. Promjena površinske tvrdoće nakon uobičajenog postupka zračenja nije se značajno razlikovala između cakline i dentina $(\mathrm{p}=0,491)$. Promjena površinske tvrdoće nakon jednokratnoga eksperimentalnog zračenja od 70 greja nije se značajno razlikovala između cakline i dentina $(\mathrm{p}=0,798)($ slike $2-5)$.

Nakon oba uobičajena postupka ozračivanja (2 Gy tijekom 35 dana) ili jedne eksperimentalne ekspozicije od 70 greja, statistički se značajno povećala srednja hrapavost površine obaju tvrdih zubnih tkiva $(<0,001)$ (tablica 2.). Promjena hrapavosti cakline nakon izlaganja zračenju nije značajno varirala u odnosu prema vrsti zračenja i dozi $(\mathrm{p}=0,282)$. Promjena hrapavosti dentina nije se značajno razlikovala $s$ obzirom na vrstu zračenja $(\mathrm{p}=0,462)$. Promjena hrapavosti nakon uobičajenog postupka zračenja nije se značajno razlikovala između cakline i dentina $(\mathrm{p}=0,485)$. Promjena hrapavosti nakon jednokratnoga eksperimentalnog zračenja od 70 greja nije se značajno razlikovala između cakline i dentina (p $=0,081)($ slike $6-9)$.

Table 1 The change in microhardness (VHN) after irradiation compared to the initial measurement (the observed variable is base irradiation).

Tablica 1. Promjena mikrotvrdoće (HV) nakon zračenja u odnosu prema početnom mjerenju (varijabla koju promatramo je base - zračenje)

\begin{tabular}{|c|c|c|c|c|c|c|c|c|}
\hline Tissue $\bullet$ Područje & Treatment $\bullet$ Tretman & $\mathbf{n}$ & $\begin{array}{l}\text { Mean } \\
\text { Prosjek }\end{array}$ & Std & $\begin{array}{l}\text { Median • } \\
\text { Medijan }\end{array}$ & $\begin{array}{c}\text { 1. quartile } \\
\text { 1. kvartil }\end{array}$ & $\begin{array}{c}\text { 3. quartile } \\
\text { 3. kvartil }\end{array}$ & $\underset{\text { p-vrijednost }^{\mathrm{a}}}{\mathrm{p} \text {-value }}$ \\
\hline Enamel • Caklina & $70 \mathrm{~Gy} \bullet$ Jako zračenje & 20 & 11,4 & 7,0 & 11,4 & 6,7 & 16,2 & $<0,001$ \\
\hline Dentin & 70 Gy • Jako zračenje & 20 & 11,0 & 7,5 & 10,8 & 5,5 & 15,4 & $<0,001$ \\
\hline Enamel $\bullet$ Caklina & 2x35 Gy • Slabo zračenje & 20 & 11,2 & 6,4 & 11,1 & 6,7 & 14,0 & $<0,001$ \\
\hline Dentin & 2x35 Gy • Slabo zračenje & 20 & 12,2 & 7,3 & 10,8 & 7,8 & 15,9 & $<0,001$ \\
\hline
\end{tabular}

Table 2 The change in surface roughness $(\mu \mathrm{m})$ after irradiation in relation to the initial measurement (the observed variable is base irradiation).

Tablica 2. Promjena hrapavosti (Ra) nakon zračenja u odnosu prema početnom mjerenju (varijabla koju promatramo je base - zračenje)

\begin{tabular}{|c|c|c|c|c|c|c|c|c|}
\hline Tissue $\bullet$ Područje & Treatment $\bullet$ Tretman & $\mathbf{n}$ & $\begin{array}{l}\text { Mean • } \\
\text { Prosjek }\end{array}$ & Std & $\begin{array}{l}\text { Median • } \\
\text { Medijan }\end{array}$ & $\begin{array}{c}\text { 1. quartile • } \\
\text { 1. kvartil }\end{array}$ & $\begin{array}{c}\text { 3. quartile • } \\
\text { 3. kvartil }\end{array}$ & $\underset{\text { p-vrijednost }^{\mathrm{a}}}{\text { p-value }^{\mathrm{a}}}$ \\
\hline Enamel $\bullet$ Caklina & $70 \mathrm{~Gy} \bullet$ Jako zračenje & 20 & -0.11 & 0.08 & -0.10 & -0.15 & -0.04 & $<0.001$ \\
\hline Dentin & 70 Gy • Jako zračenje & 20 & -0.07 & 0.06 & -0.09 & -0.11 & -0.02 & $<0.001$ \\
\hline Enamel • Caklina & 2x35 Gy • Slabo zračenje & 20 & -0.09 & 0.07 & -0.09 & -0.12 & -0.04 & $<0.001$ \\
\hline Dentin & 2x35 Gy • Slabo zračenje & 20 & -0.07 & 0.05 & -0.10 & -0.10 & -0.07 & $<0.001^{b}$ \\
\hline
\end{tabular}

${ }^{a} \mathrm{P}$-value $\mathrm{t}$-test for dependent samples. $\bullet \mathrm{P}$ - vrijednost $\mathrm{t}$-testa za zavisne uzorke

${ }^{b}$ Due to deviations from the normal distribution, the Wilcoxon Signed Rank test was used. • Zbog odstupanja od normalne distribucije korišten je Wilcoxonov Signed Rank test 


\section{2}

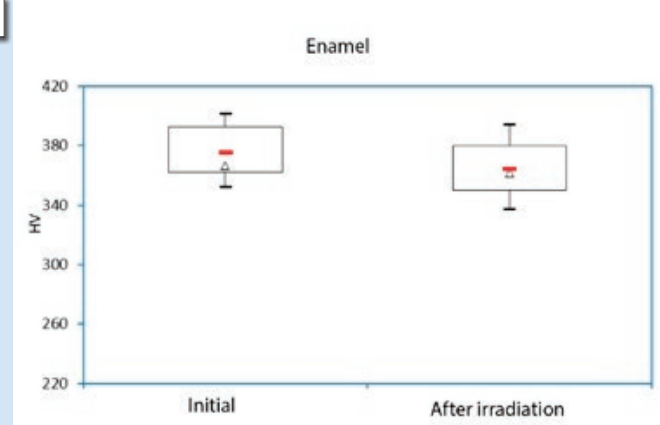

4

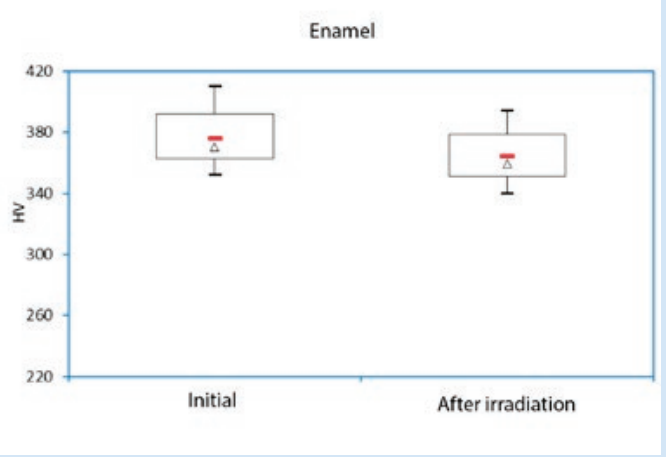

6

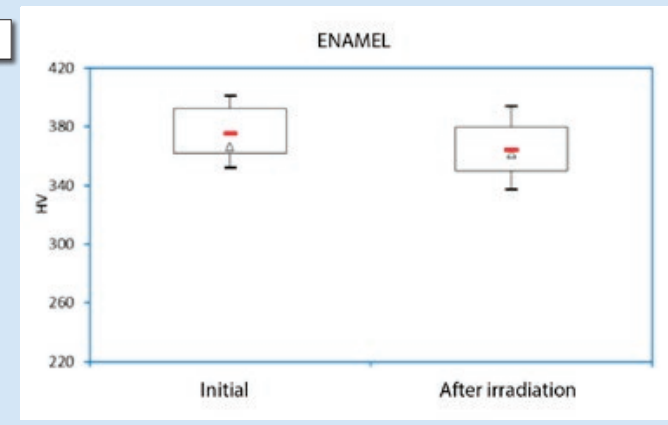

8

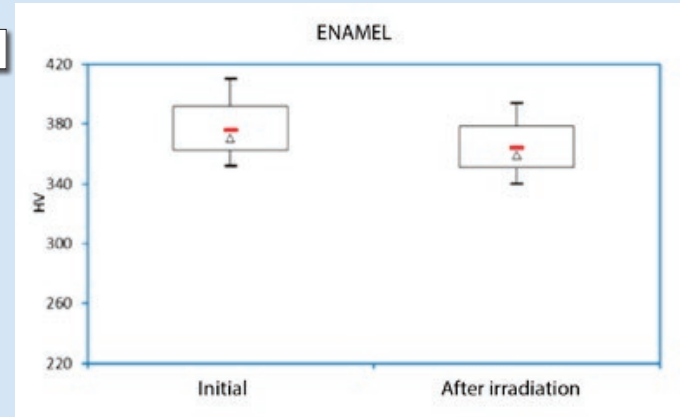

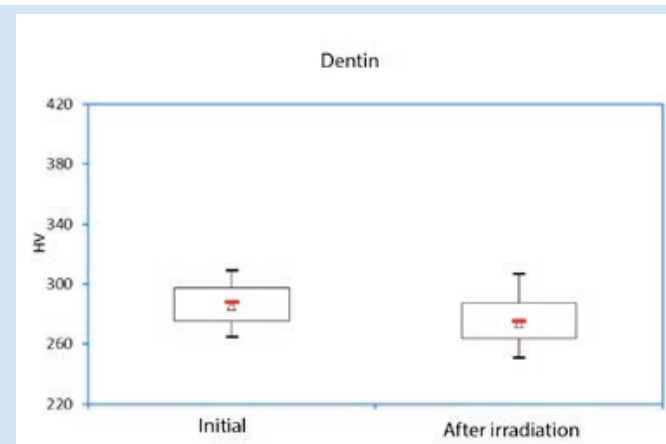

3

Dentin

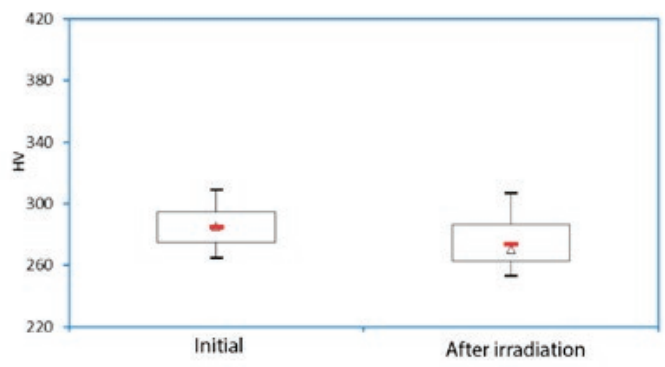

DENTIN
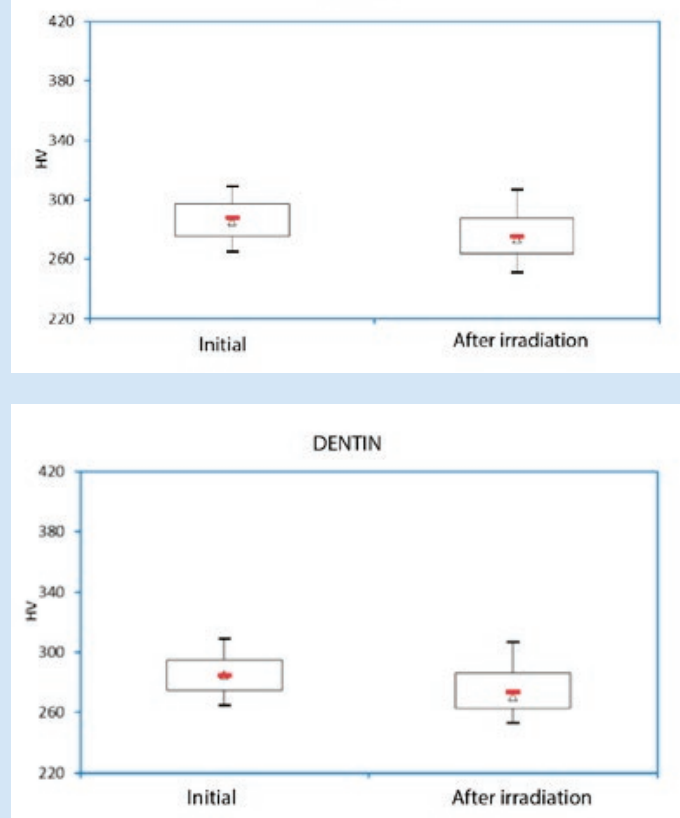

Figure 2 Box plot diagrams of enamel microhardness (VHN) distribution for standard irradiation Slika 2. Dijagrami raspodjele mikrotvrdoće cakline (VHN) za standardno zračenje

Figure 3 Box plot diagrams of dentin microhardness (VHN) distribution for standard irradiation

Slika 3. Box plot dijagrami raspodjele mikrotvrdoće dentina (VHN) za standardno zračenje

Figure 4 Box plot diagrams of enamel microhardness (VHN) distribution for experimental irradiation

Slika 4. Dijagrami raspodjele mikrotvrdoće cakline (VHN) za eksperimentalno zračenje

Figure 5 Box plot diagrams of dentin microhardness (VHN) distribution for experimental irradiation

Slika 5. Box plot dijagrami raspodjele mikrotvrdoće dentina (VHN) za eksperimentalno zračenje

Figure 6 Box plot diagrams of enamel surface roughness $(\mu \mathrm{m})$ distribution for standard irradiation

Slika 6. Dijagrami raspodjele hrapavosti površine cakline $(\mu \mathrm{m})$ za standardno zračenje

Figure 7 Box plot diagrams of dentin surface roughness $(\mu \mathrm{m})$ distribution for standard irradiation

Slika 7. Box plot dijagrami raspodjele hrapavosti površine dentina $(\mu \mathrm{m})$ za standardno zračenje

Figure 8 Box plot diagrams of enamel surface roughness $(\mu \mathrm{m})$ distribution for experimental irradiation

Slika 8. Dijagrami raspodjele hrapavosti površine cakline $(\mu \mathrm{m})$ za eksperimentalno zračenje

Figure 9 Box plot diagrams of dentin surface roughness $(\mu \mathrm{m})$ distribution for experimental irradiation

Slika 9. Dijagrami raspodjele hrapavosti površine dentina $(\mu \mathrm{m})$ za eksperimentalno zračenje 


\section{Discussion}

Head and neck malignant diseases are fairly common these days, with over 550,000 cases diagnosed each year throughout the world. At present, it is the seventh most prevalent cancer, as well as the seventh most common cause of cancer-related mortality (18). For head and neck irradiation, high-energy radioactive elements and particle accelerators are now commonly used. They work either directly by inducing the breaking of DNA strands or indirectly by producing the tissue necrosis. It can be used as a last-resort treatment following surgery, with or without chemotherapy. Radiation to these specific areas can harm healthy adjacent tissues such as bones, mucosa, dental tissue, and salivation glands, which are not adequately protected. Furthermore, the head and neck architecture is complex, and all systems, including digestive, respiratory, masticatory, and endocrine, are contained inside a very compact space. Modern oncology recommends employing "standard fractionation," which consists of a total of 65 to 72 Gy of high-energy irradiation divided into 1.8 to 2 Gy daily fractions (treatment series). These fractions are delivered over the period of seven weeks, five days every week $(19,20)$. Because of the accurate irradiation beam, normal tissue is not excessively bombarded, and toxicity is reduced, while greater doses are administered to tumors without sacrificing control rates (21).

Radiation in the head and neck area can cause changes in crystal structure, increased enamel meltability, decreased microhardness, and radiation-related caries, among other things (16). The results of this study either show that ionizing radiation can cause a dose-dependent increase or a decrease in dental hard tissues microhardness. De Siqueira Mellara et al. (22) found that accumulative dosage of 60 Gy resulted in the superior surface hardness values when compared to enamel without irradiation effect, which was in contrast to previous studies which had found that either the surface hardness of irradiated enamel is lower in position than that of non-irradiated (23), which is similar to our findings, or that there is no alteration in surface hardness as a role of irradiation (24, 25). Lu et al. (26) reported a decrease in surface hardness after exposition to $30 \mathrm{~Gy}$, but it showed that when the dose was close to $60 \mathrm{~Gy}$, the breakdown was even worse, which is similar to previous findings which revealed that exposition to $30 \mathrm{~Gy}$ arose in lowering surface microhardness and elastic modality of enamel near the dentin-enamel binding but without alteration in the middle of enamel or dentin after exposition to $60 \mathrm{~Gy}(27,28)$. Impaired microhardness and modus of elasticity at the dentin-enamel binding may limit tooth distortion throughout mastication (28), potentially resulting in enamel pilling a several weeks after irradiation (29). When compared to the non-exposed group, irradiation with $60 \mathrm{~Gy}$ induced a drop in microhardness of enamel and dentin, as well as declines in structural components (30). A number of other studies have documented potential changes following direct induced radiation, such as an enhancement in surface hardness of hard tooth structures $(26,27)$, as well as a decrease $(31,32)$ in cumulative microhardness of enamel and dentin after this specific area irradiation protocol. Goncalves

\section{Rasprava}

Zloćudne bolesti glave i vrata danas su dosta česte - svake godine diljem svijeta dijagnosticira se više od 550000 slučajeva. Trenutačno su sedmi najčešći oblik raka te sedmi najčešći uzrok smrti od raka (18). Za zračenje glave i vrata danas se obično koriste viskoenergijski radioaktivni elementi i akceleratori čestica. Djeluju ili izravno lomeći lanac DNK ili neizravno proizvodeći nekrozu tkiva. Zračenje se provodi kao posljednja mjera nakon operacije, $s$ kemoterapijom ili bez nje. Zračenje tih specifičnih područja može oštetiti zdrava susjedna tkiva kao što su kosti, sluznica, zubno tkivo i salivarne žlijezde koje nisu adekvatno zaštićene. Nadalje, struktura glave i vrata je složena, a svi sustavi, uključujući probavni, dišni, žvačni i endokrini, nalaze se unutar vrlo kompaktnog prostora. Moderna onkologija preporučuje korištenje "standardnoga frakcioniranja" koje se sastoji od 65 do 72 greja visokoenergijskoga zračenja podijeljenih u dnevne frakcije od 1,8 do 2 greja (serija tretmana). Te se doze primjenjuju sedam tjedana - pet dana tijekom tjedna $(19,20)$. Zbog preciznoga snopa zračenja normalno tkivo nije toliko bombardirano, a toksičnost je smanjena. Veće doze određuju se za tumore bez smanjivanja ukupne doze (21).

Zračenje u području glave i vrata može, između ostaloga, prouzročiti promjene u kristalnoj strukturi, povećanu topljivost cakline, smanjenu mikrotvrdoću i rani razvoj karijesa prouzročen zračenjem (16). Rezultati ovog istraživanja pokazuju da ionizirajuće zračenje može povećati ili smanjiti mikrotvrdoću tvrdih zubnih tkiva, ovisno o dozi. De Siqueira Mellara i suradnici (22) otkrili su da akumulirano zračenje od 60 greja rezultira povećanim vrijednostima površinske tvrdoće u usporedbi s caklinom bez učinka zračenja, što je bilo u suprotnosti s prijašnjim studijama u kojima se tvrdilo da je površinska tvrdoća ozračene cakline niža od tvrdoće neozračene cakline (23), što je bilo slično našim nalazima, ili da nema promjene u površinskoj tvrdoći zbog zračenja (24, 25). Lu i suradnici (26) izvijestili su o smanjenju površinske tvrdoće nakon izlaganja zračenju do 30 greja, ali kada je doza bila blizu 60 greja oštećenje je bilo još veće, što je slično prethodnim nalazima u kojima se ističe da izlaganje do 30 greja rezultira smanjenjem površinske mikrotvrdoće i elastičnoga modula cakline u blizini veze dentin - caklina, ali bez promjene u sredini cakline ili dentina nakon izlaganja zračenju od 60 greja $(27,28)$. Narušena mikrotvrdoća i modul elastičnosti na spoju dentina i cakline mogu ograničiti distorziju zuba tijekom žvakanja (28) i potencijalno rezultirati odlamanjem cakline nekoliko tjedana nakon zračenja (29). U usporedbi s neeksponiranom skupinom, zračenje od 60 greja smanjilo je mikrotvrdoću cakline i dentina te snizilo vrijednosti gradivnih komponenti (30). U mnogobrojnim studijama autori su zabilježili potencijalne promjene nakon izravnoga učinka zračenja, kao što su povećanje površinske tvrdoće tvrdih zubnih struktura $(26,27)$ i smanjenje $(31,32)$ kumulativne mikrotvrdoće cakline i dentina nakon zračenja specifičnih područja. Goncalves i suradnici (27) pronašli su smanjenje mikrotvrdoće cakline u vanjskim slojevima do ukupne doze od 30 greja, ali povećanje $s$ većim dozama. Nakon akumuliranih doza zračenja od 10, 30, 40, 50 i 60 greja, mikro- 
et al. (27), for example, found a reduction in enamel microhardness in exterior layers up to $30 \mathrm{~Gy}$ accumulative dosages, but there was an augmentation with higher doses. After accumulative irradiation dosages of 10, 30, 40, 50, and $60 \mathrm{~Gy}$, microhardness in the midsection of enamel did not differ significantly from non-exposed enamel, but microhardness in lower layers of enamel did not alter. When compared to nonexposed dentin, dentin microhardness reduced after 10, 20, 30, 50, and 60 Gy cumulative irradiation doses. This finding was opposite to ours where the change in microhardness of hard dental tissues after radiation did not result in significant difference in comparison to radiation tenacity, meaning that higher irradiation dosage did not end with more alteration. After both, conventional irradiation protocol $(2 \mathrm{~Gy}$ for 35 days) or powerful, exploratory dose of 70 Gy there was a significant reduction in the mean microhardness of both dental tissues with no distinction to irradiation tenacity, hence the first null hypothesis that there is no distinction in ways of microhardness between the non-exposed teeth was consequently rejected, while the second hypothesis that there is no distinction between the various irradiation proceedings was completely accepted. Gülsüm et al. (28) reported that surface hardness of enamel reduced (from top to inner structures) with augmentation of radiation dosage up to $60 \mathrm{~Gy}$ and other papers reported a reduction in upper layers of dentin structural hardness (33-35) which is later elucidated with more water composition inside of dentin (10\%), occultation of dentin tubuli, destruction of collagen layer and stronger potential of free radicals disengaged post radiation (36), which can be compared to our findings where both irradiation protocols led to reduction in the mean microhardness of hard tissues, while their surface roughness enlarged significantly. Rodriguez et al. (37) reported that accumulative irradiation of 30 and 60 Gy resulted in no surface changes, especially in the prism construction, but the space between the prisms is bigger with the augmentation of the irradiation dosage. Prism composition of irradiated enamel stayed unchanged irrespective to irradiation dosages. A small structural alteration was noted in the space between the prisms after 30 Gy irradiation dosages. Dentin of non-exposed teeth resulted in wellformed dentin tubuli and collagen layer but with enhanced superficial structure change in post irradiation period using 30 and 60 Gy (37). Our study reported that stronger higher irradiation dose could lead to severe damage, and can be result of intense radiation outcome, which can affect the structure of enamel and dentin. This was also reported in findings by Ferraz et al. (38) who stated that lower saliva flow, which can be affected with radiation, had lower ability for remineralization of enamel in comparison to regular flow. Previous investigations reported that the radiation therapy in a number of smaller doses is used to evade the negative change in saliva excretion or damage of adjacent structures dealing with dose cumulation (39), hence our experiment of applying one strong dose of $70 \mathrm{~Gy}$, which is not clinically authorized, showed that the number of severe destructions of hard dental tissues was smaller than in cases when more cumulated dosages are applied; however, it is not yet recommended for application to living patients. Scientific reports dealing with tvrdoća u središnjem dijelu cakline nije se značajno razlikovala od neeksponirane cakline, ali se mikrotvrdoća u donjim slojevima cakline nije mijenjala. U usporedbi s neeksponiranim dentinom, mikrotvrdoća dentina smanjena je nakon kumulativnih doza zračenja od 10, 20, 30, 50 i 60 greja. Taj je nalaz bio suprotan našemu u kojem promjena mikrotvrdoće tvrdih zubnih tkiva nakon zračenja nije rezultirala značajnom razlikom u odnosu prema vrsti I količini zračenja, što znači da veća doza zračenja nije završila s većim promjenama. Nakon obaju konvencionalnih protokola zračenja (2 Gy tijekom 35 dana) ili snažne, eksperimentalne, jednokratne doze od 70 greja, dogodilo se značajno smanjenje srednje mikrotvrdoće obaju zubnih tkiva bez ovisnosti o vrsti zračenja, pa se prva nulta hipoteza da nema razlike u mikrotvrdoći između ozračenih i neozračenih zuba posljedično odbacuje, a druga hipoteza da nema razlike između različitih postupaka zračenja potpuno se prihvaća. Gülsüm i suradnici (28) ustanovili su da se površinska tvrdoća cakline smanjuje (od vrha prema unutarnjim strukturama) s povećanjem doze zračenja do 60 greja, a u drugim radovima navodi se smanjenje u gornjim slojevima strukturne tvrdoće dentina $(33-35)$, što se poslije objašnjava većom količinom vode unutar dentina (10\%), začepljenošću dentinskih tubulusa, destrukcijom kolagenskoga sloja i jačim potencijalom oslobađanja slobodnih radikala nakon zračenja (36). To se može usporediti s našim nalazima u kojima su oba protokola zračenja rezultirala smanjenjem srednje mikrotvrdoće tvrdih tkiva, dok je njihova površinska hrapavost značajno povećana. Rodriguez i suradnici (37) izvijestili su da kumulativno zračenje od 30 i 60 greja nije rezultiralo promjenom površine, posebno u izgledu caklinskih prizmi, ali je prostor između njih postao veći s povećanjem doze zračenja. Sastav prizme ozračene cakline ostao je nepromijenjen bez obzira na doze zračenja. Mala strukturna promjena zabilježena je u prostoru između prizma nakon doze zračenja od 30 greja. Dentin neeksponiranih zuba rezultirao je dobro oblikovanim dentinskim tubulusima i slojem kolagena, ali s pojačanom promjenom površinske strukture $\mathrm{u}$ razdoblju poslije zračenja primjenom 30 i 60 greja (37). Naša studija pokazala je da veće doze zračenja mogu prouzročiti teška oštećenja i mogu biti rezultat intenzivnog ishoda zračenja koje može utjecati na strukturu cakline i dentina, što je također navedeno u nalazu Ferraza i suradnika (38) - oni su zabilježili da manji protok sline na koji se može utjecati zračenjem ima i manje svojstvo remineralizacije cakline u odnosu prema normalnom protoku. Dosadašnja istraživanja pokazala su da radioterapija u nekoliko manjih doza ne potiče negativne promjene u izlučivanju sline ili oštećenju susjednih struktura (39) pa je naš eksperiment s primjenom jedne jake doze od 70 greja, koji nije bio klinički odobren, potvrdio da nema daljnjeg uništavanja tvrdoga zubnog tkiva osim ako se primjenjuju veće kumulirane doze, no još se uvijek ne može koristiti na živim pacijentima. Znanstvena izvješća koja se bave jednom eksperimentalnom dozom od 70 greja linearnom akceleratorskom jedinicom nisu česti predmet istraživanja, ali mogu se usporediti s radom Piocha i suradnika (40) koji nisu upotrijebili frakcioniranu dozu, nego jednu dozu od 70 greja, ali s izvorom kobalta-60 i zabilježili su blaga oštećenja na spoju cakline i dentina. 
one experimental dose of 70 Gy by linear accelerator unit are not frequent in previous papers, apart from one paper by Pioch et al. (40) who did not use fractionated dose. One dose of $70 \mathrm{~Gy}$ was used with cobalt-60-source, and transiency in the part of the dentin-enamel constriction was observed.

Nowadays, linear accelerator for radiotherapy is beneficial, mostly for $360^{\circ}$ rotation, thus allowing the tissue to accumulate only relevant to specific treatment, while the adjacent soft and hard structures and organs are at smaller jeopardy (41). Despite its benefits, this procedure is rather costly, and it is not the preferred option in all nations. Even with the use of this approach and distributed dosages, the hard dental tissues are closer to the referred region in clinical practice, and exposition of hard dental structures cannot be evaded (9).

When assessing changes in surface hardness and roughness of hard tooth structures after radiotherapy, measuring methods can have an influence on final outcomes. Since dry surroundings can affect the mechanical characteristics of tooth sample which is connected to dehydration and can result in reduced surface hardness, one of the main consequences is humidity of the tissue during experimental measuring (41). Between measurements, the dental samples were kept in deionized water in our investigation. Other investigations have found that radiotherapy on sterilized extracted teeth, showed no substantial changes in the mechanical qualities or chemical composition of hard tissues $(42,43)$. Differences in storage type and duration of tooth specimens can have an impact on surface hardness values $(44,45)$, as well as which part of the tooth sample served for measuring (46). Finally, one of the most important reasons for microhardness data difference is the variation across teeth of different patients, even within the same sample $(47,48)$.

Different approaches, such as scanning electron microscopy or surface roughness, can be used to determine the surface structure. There was a statistically significant increase in the average surface roughness of all hard tissues after both, the usual radiotherapy procedure and one dose of $70 \mathrm{~Gy}$, which resulted in rejecting the first hypothesis which stated that there is no difference in surface roughness between the non-exposed and the irradiated teeth. The change in hard tissues roughness after radiotherapy was not significantly different in terms of irradiation tenacity, therefore, the second hypothesis claiming that there were no differences between various radiotherapy procedures of surface roughness was accepted. Our findings could not be easily compared to other studies since there is the lack of other studies dealing with surface roughness following irradiation of these specific hard tissues. Based on the results, we can only assume that both irradiation techniques damage the surface by increasing roughness. Few SEM studies dealing with irradiation effect obtained similar results which can be partially compared to our findings related to surface roughness. Gülsüm et al. (28) reported that the when irradiation dosage enhances, some amorphous formations can be created on the upper layers of hard dental tissues leading to superficial fissures on the irradiated enamel surfaces, while de Siqueira Mellara et al. (22) observed a gradual deterioration of enamel and dentin structure connected to en-
Danas linearni akcelerator za radioterapiju ima mnogo prednosti i rotaciju od $360^{\circ}$, što dopušta tkivu da akumulira samo relevantno malo zračenja, onoliko koliko je nužno za specifično liječenje; pritom su susjedne meke i tvrde strukture i organi u manjoj opasnosti (41). Unatoč prednostima taj je postupak prilično skup i nije široko dostupan. Čak i uz korištenje toga pristupa i malih raspoređenih doza, tvrda zubna tkiva nalaze se u regiji zračenja te se u kliničkoj praksi izlaganje i potencijalno oštećenja zubnih struktura ne može izbjeći (9).

Pri procjeni promjena u površinskoj tvrdoći i hrapavosti tvrdih zubnih struktura nakon radioterapije, mjerne metode mogu utjecati na konačni ishod. Budući da suha okolina može utjecati na mehaničke karakteristike uzorka zuba, što je povezano s dehidracijom i može se očitovati u smanjenoj površinskoj tvrdoći, jedna od glavnih posljedica jest vlažnost tkiva tijekom eksperimentalnog mjerenja (41). Između mjerenja su dentalni uzorci u našem istraživanju držani u deioniziranoj vodi. U drugim istraživanjima ističe se da radioterapija steriliziranih izvađenih zuba nije pokazala značajnu promjenu u mehaničkim kvalitetama ili kemijskom sastavu tvrdih tkiva $(42,43)$. Razlike u načinu skladištenja uzoraka zuba mogu utjecati na vrijednosti površinske tvrdoće $(44,45)$ i na to koji je dio uzorka zuba služio za mjerenje (46). Konačno, jedan od najvažnijih razloga za razliku u podatcima o mikrotvrdoći jest varijacija između zuba različitih pacijenata, čak i unutar istog uzorka (47).

$\mathrm{Za}$ određivanje površinske strukture mogu se koristiti različiti pristupi, poput skenirajuće elektronske mikroskopije ili mjerenja hrapavosti površine. U našem istraživanju zabilježeno je statistički značajno povećanje prosječne hrapavosti površine svih tvrdih tkiva i nakon uobičajenoga radioterapijskoga zahvata i jedne doze od 70 greja, što je rezultiralo odbacivanjem prve hipoteze da nema razlike u površinskoj hrapavosti između neeksponiranih i zračenih zubi. Promjena hrapavosti tvrdih tkiva nakon radioterapije nije se značajno razlikovala kad je riječ o postojanosti zračenja, pa je prihvaćena druga hipoteza koja objašnjava da nema razlike između različitih radioterapijskih postupaka hrapavosti površine.

Naši se nalazi ne mogu jednostavno usporediti s onima u drugim studijama zbog nedostatka sličnih koje su se bavile temom hrapavosti površine tvrdih zubnih tkiva nakon zračenja, ali na temelju rezultata možemo samo pretpostaviti da obje tehnike zračenja oštećuju površinu i povećavaju hrapavost. Nekoliko SEM studija koje se bave učinkom zračenja pokazale su slične rezultate koji se mogu djelomično usporediti s našim nalazima o hrapavosti površine. Gülsüm i suradnici (28) izvijestili su da, kada se doza zračenja poveća, na gornjim slojevima tvrdih zubnih tkiva mogu se stvoriti amorfne formacije koje završavaju površinskim fisurama na ozračenoj površini cakline, a de Siqueira Mellara i suradnici (22) uočili su postupno oštećenje strukture cakline i dentina koje je povezano s povećanom dozom zračenja. Primjenom triju različitih doza zračenja (20, 40 i 70 Gy) nije bilo drukčijeg učinka na cervikalni, srednji i okluzalni dio cakline bez ikakvih morfoloških promjena ili promjena u mineralnom sastavu (33). 
larged irradiation dosage. Using three distinct radiation doses (20, 40, and 70Gy), had no different effect on cervical, middle, and occlusal part of enamel without any morphological or mineral alteration (33).

Our findings were based on extracted teeth in laboratory conditions and the main purpose was to find the difference between various radiotherapy solutions on hard dental tissues. Due to in vitro study restrictions, an important conclusion can be drawn: direct irradiation can result in possible destruction of enamel and dentin with reduction in surface hardness and enlarged roughness irrespective of the irradiation technique. This study has some drawbacks. The position of enamel buds and crystals, as well as the position of dentin tubuli, determine the mechanical qualities of hard dental tissues. Teeth are more likely to be exposed to smaller values of irradiation in the mouth during the real in vivo radiotherapy treatment than in the tentative laboratory setting. On the basis of this study and other research, we are still a long way from reaching a consensus about the optimal clinical approach, potential materials for restoration of hard dental tissues and strategies for people who may face a number of complications in the future. In order to obtain a better understanding of direct effects of irradiation on teeth and adjacent soft tissues, further in-vivo studies are needed.

\section{Conclusions}

This paper has confirmed the fact that, despite various irradiation procedures, direct effects of radiotherapy can result in possible breakdown of hard dental structures. Bearing in mind the potential limitations (no saliva, extraoral conditions, extracted teeth, etc.), but in compliance with aforementioned studies, a particular concern should be taken about hard and soft oral tissues after standard irradiation protocol of head and neck radiotherapy. Various conclusions in the abovementioned studies point out that there is not a concise piece of information in the area of irradiation and hard dental structures, and that further studies dealing with possible remineralization processes and different requirements are needed.

\section{Conflict of interest}

No conflict of interest

\section{Acknowledgements}

This study was supported by Grant of University of Zagreb, year 2020/2021.

Author's contribution: E.K.S. - scientific and intellectual contribution; A.T. - scientific and intellectual contribution; J.K.- scientific and intellectual contribution; M.S. - scientific contribution; T.G. - scientific contribution.
Naši su se nalazi temeljili na podatcima dobivenima na ekstrahiranim zubima u laboratorijskim uvjetima, a glavna svrha bila je uočiti razliku između različitih radioterapijskih postupaka na tvrdim zubnim tkivima. Zbog ograničenja ove studije in vitro mogu se zaključiti dvije važne stvari - izravno zračenje može oštetiti caklinu i dentin, uz smanjenje površinske tvrdoće i povećanu hrapavost neovisno o vrsti zračenja. No ova studija ima i velike nedostatke. Za zube će vjerojatno biti utvrđene manje vrijednosti zračenja u ustima tijekom stvarne radioterapije in vivo, nego u laboratorijskim uvjetima. Na temelju ovoga i drugih istraživanja još smo daleko od dogovora o optimalnom kliničkom pristupu, potencijalnim materijalima za restauraciju tvrdih zubnih tkiva i strategijama za ljude koji bi se mogli suočiti s nizom komplikacija kao posljedicama radioterapije glave i vrata. Za daljnje razumijevanje izravnih učinaka zračenja na zube i susjedna meka tkiva, potrebne su studije in vivo.

\section{Zaključak}

U ovome radu istaknuto je da izravan učinak radioterapije može rezultirati oštećenjem tvrdih zubnih struktura, nevezano o kojemu načinu zračenja je riječ. Prema ovim rezultatima i imajući na umu potencijalna ograničenja studije (nekorištenje sline, ekstraoralno mjerenje, izvađeni zubi i sl.), ali u skladu s prije navedenim studijama, nakon standardnoga protokola zračenja radioterapije glave i vrata treba uzeti u obzir pojavu mogućih oštećenja tvrdih zubnih struktura i okolnih mekih tkiva. Različiti zaključci u navedenim radovima ističu da nema evidentnih i konzistentnih informacija i zaključaka u području zračenja i tvrdih zubnih struktura te da su za daljnja istraživanja nužne slične studije koje se bave mogućim utjecajem različitih postupaka remineralizacije na tvrda zubna tkiva.

\section{Sukob interesa}

Nije bilo sukoba interesa.

\section{Zahvala}

Ovo istraživanje obavljeno je zahvaljujući stipendiji Sveučilišta u Zagrebu za mala istraživanja (godina 2020./2021.).

Doprinos autora: E. K. S. - znanstveni i intelektualni doprinos; N. A. - znanstveni i intelektualni doprinos; J. K. - znanstveni i intelektualni doprinos; M. S. - znanstveni doprinos; T. G. - znanstveni doprinos. Svi autori autorizirali su završni rad. 
Sažetak

Uvod: Radioterapija se primjenjuje u liječenju neoplazmatskih lezija, a uobičajene nuspojave u tom procesu obično su bol, oteklina i osjetljivost sluznice u području zračenja, smanjeno izlučivanje sline, karijes, parodontna bolest i smanjena kvaliteta života. Svrha ovog istraživanja bila je procijeniti učinak izravnoga zračenja na fizičke i površinske karakteristike tvrdih zubnih tkiva. Materijali i metode: Istraživanje je provedeno na 20 trećih kutnjaka bez karijesa. Prije primjene različitih protokola zračenja, polovine zuba raspoređene su u ispitnu i kontrolnu skupinu metodom nasumičnog izvlačenja. Prva skupina $(n=20)$ podvrgnuta je konvencionalnom protokolu zračenja (2 Gy tijekom 35 da$n a)$, druga skupina $(n=20)$ bila je izložena jednoj snažnoj, eksperimentalnoj dozi od 70 greja (Gy). Svaki uzorak služio je kao vlastita kontrola. Zračenje je provedeno radioterapijskom jedinicom linearnog akceleratora. Mikrotvrdoća i hrapavost površine mjerene su na početku (početna) i na kraju postupka zračenja. Prosječna promjena mikrotvrdoće i hrapavosti nakon različitih tretmana uspoređena je t-testom za nezavisne uzorke. Normalnost je testirana Shapiro-Wilkovim testom. Rezultati: Uočene su značajne razlike nakon standardnoga protokola zračenja i eksperimentalne doze od 70 greja, uz smanjenu prosječnu mikrotvrdoću i povećanu prosječnu hrapavost $(p<0,001)$ obaju tvrdih zubnih tkiva. Mikrotvrdoća i hrapavost površine cakline i dentina nisu se značajno razlikovale s obzirom na različite protokole zračenja. Zaključak: Standardni protokol zračenja glave i vrata može oštetiti caklinu i dentin, uz smanjenu mikrotvrdoću i povećanu hrapavost površine bez obzira na korišteni protokol zračenja.
Zaprimljen: 22. kolovoza 2021.

Prihvaćen: 20. listopada 2021.

Adresa za dopisivanje izv. prof. Eva Klarić Sever

Sveučilište u Zagrebu

Stomatološki fakultet

Zavod za endodonciju i restaurativnu

stomatologiju

Gundulićeva 5

10000 Zagreb, Hrvatska

eklaric@sfzg.hr

MeSH pojmovi: dentin; zubna caklina; površinska svojstva; liječenje ionizirajućim zračenjem; dugotrajni neželjeni učinci

Autorske ključne riječi: konvencionalno zračenje; tvrdoća prema Vickersu; hrapavost; tvrda zubna tkiva

\section{References}

1. Argiris A, Karamouzis MV, Raben D, Ferris RL. Head and neck cancer. Lancet. 2008 May 17;371(9625):1695-709.

2. Suh JD, Cho JH. Trends in head and neck cancer in South Korea between 1999 and 2012. Clin Exp Otorhinolaryngol. 2016 Sep;9(3):263-9.

3. Gabrić D, Seiwerth S, Baraba A, Vučićević Boras V. Mandibular Osteonecrosis due to the Pulpal-Periodontal Syndrome: a Case Report and Review of the Literature. Acta Stomatol Croat. 2017 Mar;51(1):65-71.

4. Specht L. Oral complications in the head and neck radiation patient. Introduction and scope of the problem. Support Care Cancer. 2002 Jan;10(1):36-9.

5. Kelly C, Paleri V, Downs C, Shah R. Deterioration in quality of life and depressive symptoms during radiation therapy for head and neck cancer. Otolaryngol Head Neck Surg. 2007 Jan;136(1):10811.

6. Vissink A, Jansma J, Spijkervet FK, Burlage FR, Coppes RP. Oral sequelae of head and neck radiotherapy. Crit Rev Oral Biol Med. 2003;14(3):199-212.

7. Kielbassa AM, Hinkelbein W, Hellwig E, Meyer-Lu“ckel H. Radiation-related damage to dentition. Lancet Oncol. 2006 Apr;7(4):326-35.

8. Jansma J, Spijkervet FK, Burlage FR, Coppes RP. Oral sequelae of head and neck radiotherapy. Crit Rev Oral Biol Med. 2003;14(3):199-212.

9. Lieshout HF, Bots CP. The effect of radiotherapy on dental hard tissue - a systematic review. Clin Oral Investig. 2014 Jan;18(1):1724.

10. de Siqueira MT, Palma-Dibb RG, de Oliveira HF, Garcia Paula-Silva FW, Nelson-Filho P, da Silva RA, da Silva LA, de Queiroz AM. The effect of radiation therapy on the mechanical and morphological properties of the enamel and dentin of deciduous teeth - an in vitro study. Radiat Oncol. 2014 Jan 22;9:30.

11. Walker MP, Wichman B, Cheng A-L, Coster J, Williams KB. Impact of radiotherapy dose on dentition breakdown in head and neck cancer patients. Pract Radiat Oncol. 2011;1(3):142-148.

12. Franzel W, Gerlach R, Hein HJ, et al. Effect of tumor therapeutic irradiation on the mechanical properties of teeth tissue. Z Med Phys. 2006;16(2):148-54

13. Franzel W, Gerlach R. The irradiation action on human dental tis sue by X-rays and electrons--a nanoindenter study. Z Med Phys. 2009;19(1):5-10.

14. Schiødt M, Hermund NU. Management of oral disease prior to radiation therapy. Support Care Cancer. 2002 Jan;10(1):40-3.

15. Turkalj M, Šutej I, Peroš K. Comparison of fluoride ion release from fluoride gel in various solvents. Acta Stomatol Croat. 2020 Jun;54(2):147-154.

16. Effectiveness of fluoride varnish application as cariostatic and de sensitizing agent in irradiated head and neck cancer patients. Int J Dent. 2013;2013:824982.

17. Parahoo RS, Semple CJ, Killough S, McCaughan E. The experience among patients with multiple dental loss as a consequence of treatment for head and neck cancer: A qualitative study. I Dent. 2019 Mar;82:30-37.

18. Reed R, Xu C, Liu Y, Gorski JP, Wang Y. Radiotherapy effect on nano-mechanical properties and chemical composition of enamel and dentine. Arch Oral Biol. 2015 May;60(5):690-7.

19. Global Burden of Disease Cancer Collaboration. Global, Regional, and National Cancer Incidence, Mortality, Years of Life Lost, Years Lived With Disability, and Disability-Adjusted Life-years for 32 Cancer Groups, 1990 to 2015: A Systematic Analysis for the Global Burden of Disease Study. JAMA Oncol. 2017 Apr 1;3(4):524548

20. White JM, Goodis HE, Marshall SJ, Marshall GW. Sterilization of teeth by gamma radiation. J Dent Res. 1994 Sep;73(9):1560-7.

21. Nutting CM, Morden JP, Harrington KJ, Urbano TG, Bhide SA, Clark $C$, Miles EA, et al. Parotid-sparing intensity modulated versus conventional radiotherapy in head and neck cancer (PARSPORT): a phase 3 multicentre randomised controlled trial. Lancet Oncol. 2011 Feb;12(2):127-36.

22. Jellema AP, Slotman BJ, Doornaert $P$, et al. Impact of radiationinduced xerostomia on quality of life after primary radiotherapy among patients with head and neck cancer. Int J Radiat Oncol Biol Phys. 2007 Nov 1;69(3):751-60.

23. de Siqueira Mellara T, Palma-Dibb RG, de Oliveira HF, Garcia Paula-Silva FW, Nelson-Filho P, da Silva RA, da Silva LA, de Queiroz $A M$. The effect of radiation therapy on the mechanical and morphological properties of the enamel and dentin of deciduous teeth--an in vitro study. Radiat Oncol. 2014 Jan 22;9:30.

24. Poyton HG. The effects of radiation on teeth. Oral Surg Oral Med Oral Pathol. 1968 Nov;26(5):639-46.

25 . Joyston-Bechal S. The effect of X-radiation on the susceptibility of enamel to an artificial caries-like attack in vitro. J Dent. 1985 Mar;13(1):41-4.

26. De Menezes Oliveira MA, Torres CP, Gomes-Silva JM. Microstructure and mineral composition of dental enamel of permanent and deciduous teeth. Microsc Res Tech. 2010 May;73(5):572-7.

27. Lu H, Zhao Q, Guo J, Zeng B, Yu X, Yu D, et al. Direct radiationinduced effects on dental hard tissue. Radiat Oncol. 2019 Jan $11 ; 14(1): 5$.

28. Gonçalves LM, Palma-Dibb RG, Paula-Silva FW, Oliveira HF, Nelson-Filho P, Silva LA, Queiroz AM. Radiation therapy alters microhardness and microstructure of enamel and dentin of permanent human teeth. J Dent. 2014 Aug;42(8):986-92.

29. Gülsüm D, Burçin A, Öztun T. Effect of different doses of radiation on morphogical, mechanical and chemical properties of primary and permanent teeth-an in vitro study. BMC Oral Health. 2020 Sep $1 ; 20(1): 242$

30. Seyedmahmoud R, Wang Y, Thiagarajan G. Oral cancer radiother apy affects enamel microhardness and associated indentation pattern morphology. Clin Oral Investig. 2018 May;22(4):17951803.

31. Reed R, Xu C, Liu Y, Gorski JP, Wang Y, Walker MP. Radiotherapy effect on nano-mechanical properties and chemical composition of enamel and dentine. Arch Oral Biol. 2015 May;60(5):690-7. 
32. Franzel W, Gerlach R. The irradiation action on human dental tis sue by Xrays and electrons - a nanoindenter s also. Z Med Phys. 2009;19(1):5-10.

33. Qing P, Huang S, Gao S, Qian L, Yu H. Effect of gamma irradiation on the wear behavior of human tooth enamel. Sci Rep. 2015 Jun 23;5:11568.

34. de Barros da Cunha SR, Fonseca FP, Ramos P, Haddad CMK, Fregnani ER, Aranha ACC. Effects of different radiation doses on the microhardness, superficial morphology, and mineral components of human enamel. Arch Oral Biol. 2017 Aug;80:130-135.

35. Kielbassa AM, Munz I, Bruggmoser G, Schulte-Monting J. Effect of demineralization and remineralization on microhardness of irradiated dentin J Clin Dent. 2002;13(3):104-10.

36. Wu L, Geng K, Gao Q. Effects of different anti-caries agents on microhardness and superficial microstructure of irradiated permanent dentin: an in vitro study. BMC Oral Health. 2019 Jun $14 ; 19(1): 113$

37. Kielbassa AM, Wrbas KT, Schulte-Mönting J, Hellwig E. Correlation of transversal microradiography and microhardness on in situ induced demineralization in irradiated and non-irradiated human enamel. Arch Oral Biol. 1999 Mar;44(3):243-51.

38. Rodríguez-Martínez J, Valiente M, Sánchez-Martín M-J. 2019. Tooth whitening: from the established treatments to novel approaches to prevent side effects. JERD. 2019;31(5):431-40.

39. Ferraz LN, Isabele V, Gláucia M, Ambrosano B 3, Lopes M, Alves D. Effect of tooth bleaching and application of different dentifrices on enamel properties under normal and hyposalivation conditions: an in situ study. Clin Oral Investig. 2021 Oct;25(10):59295944.
40. Hoebers F, Yu E, Eisbruch A, Thorstad W, O’Sullivan B, Dawson LA, Hope A. A pragmatic contouring guideline for salivary gland structures in head and neck radiation oncology: the MOIST target. Am J Clin Oncol. 2013 Feb;36(1):70-6.

41. Pioch T, Golfels D, Staehle HJ. An experimental study of the stability of irradiated teeth in the region of the dentinoenamel junction. Endod Dent Traumatol. 1992 Dec;8(6):241-4.

42. Lewis G, Nyman JS. The use of nanoindentation for characterizing the properties of mineralized hard tissues: state-of-the art review. J Biomed Mater Res B Appl Biomater. 2008 Oct;87(1):286301.

43. Brauer DS, Saeki K, Hilton JF, Marshall GW, Marshall SJ. Effect of sterilization by gamma radiation on nano-mechanical properties of teeth. Dent Mater 2008;24(8):1137-40.

44. Gellrich NC, Schramm A, Bockmann R, Kugler J. Follow-up in patients with oral cancer. J Oral Maxillofac Surg. 2002 Apr;60(4):3806; discussion 387-8.

45. White JM, Goodis HE, Marshall SJ, Marshall GW. Sterilization of teeth by gamma radiation. J Dent Res. 1994 Sep;73(9):1560-7.

46. Habelitz S, Marshall Jr GW, Balooch M, Marshall SJ. Nanoindentation and storage of teeth. J Biomech. 2002 Jul;35(7):995-8.

47. Sultana S, Nikaido T, Asafujjoha M, Tagami J, Matin K. Storage media to preserve dentin and their effects on surface properties. Int Chin J Dent. 2006;6:123-9.

48. Park S, Wang DH, Zhang D, Romberg E, Arola D. Mechanical properties of human enamel as a function of age and location in the tooth. J Mater Sci Mater Med. 2008 Jun;19(6):2317-24. 